\title{
Economic Institutions and the Outward FDI Location Strategies of Emerging Market Multinational Business Groups: Evidence from Central and Eastern European Countries
}

\author{
Sohaib Shahzad Hassan $\bowtie$ \\ Friedrich-Schiller-University of Jena \\ and \\ Max Planck institute of Economics, \\ Germany
}

\begin{abstract}
By using an extensive data set on the outward foreign direct investment (OFDI) projects from Central and Eastern European Countries (CEECS) in the European Union (EU), this paper empirically examines how host-country economic institutions affect the OFDI location decisions of multinational business groups (Investors) from the European emerging economies, while controlling for other conventional determinants of location choice. From a data set of 24,726 location decisions of 951 CEEC investors, the robust empirical evidence presented herein suggests that a corruption-free country with a lower tax burden and favorable business regulations positively influences the international relocation decisions of investors. However, these factors vary depending on whether the host country is an advanced or an emerging economy. Moreover, the effects of economic institutions have a stronger influence on location activities in the advanced economies than they do in the emerging economies of the EU. Finally, CEEC investors generally prefer to be located in countries that have better institutions than those in their home countries.
\end{abstract}

JEL classification: F14; F23; L23; O52;

Keywords: outward FDI, conditional-logit, location choice, emerging economy multinational business groups, economic institutions, CEECs.

This research is supported by the German Research Foundation. I am grateful to the editorial team, Fulvio Castellacci and an anonymous referee of this journal for their helpful comments as well as to Uwe Cantner, Bjoern Jindra, Abiodun Egbetokun and Julia Paetz for their valuable feedback.

$\triangle$ Address: Department of Economics, Friedrich-Schiller-University of Jena, Carl-ZeissStrasse 3, D-07743, Jena, Germany. (Phone: +49 3641 943273. Email: sohaib.hassan@unijena.de).

\section{Recommended Citation}

Hassan, S.S. (2015). Economic Institutions and the Outward FDI Location Strategies of Emerging Market Multinational Business Groups: Evidence from Central and Eastern European Countries. Review of Economics and Institutions, 6(1), Article 6. doi: 10.5202/rei.v6i1.139.

Retrieved from http://www.rei.unipg.it/rei/article/view/139 


\section{Introduction}

The question of whether the economic institutions in host countries influence where multinational business groups decide to locate their foreign affiliates through Outward Foreign Direct Investment (OFDI) has thus far been largely analyzed for the OFDI activities of business groups from advanced economies (e.g., Daude and Stein, 2007). However, the significant rise in OFDI from emerging economies ${ }^{1}$ has heightened the need to address this issue in the context of multinational business groups from emerging economies (EMBGs hereafter) $\mathrm{I}^{2}$

While previous studies of business groups in emerging economies have explored the dynamics of home institutions in the evolution (Khanna and Palepu, 2000; Khanna and Yafeh, 2007), internationalization (Kock and Guillén, 2001; Peng et al., 2008; Yang et al., 2009) and cross-country performance of EMBGs (Chacar, 2010; Castellacci, 2013), little is known about how the host-country institutional environment affects the foreign location strategies of EMBGs. Previous research has demonstrated that EMBGs emanate from distinct economic and institutional environments that shape their organizational patterns and strategies (Khanna and Palepu, 1997; Hoskisson et al., 2000; Khanna and Yafeh, 2007; Ramamurti, 2009). EMBGs are generally associated with different (often weak) ownership characteristics specific to their home countries (e.g., lower levels of economic, institutional and technological development), their late arrival into the international business scene and limited resources, which typically influence their internationalization strategies (Kock and Guillén 2001; Child and Rodriguez, 2005; Buckley et al., 2007; Ramamurti, 2012). Indeed, an increasing number of studies have extended conventional internationalization theory to explain the international dispersion motives and location activities of EMBGs (e.g., Mathews, 2002, 2006; Luo and Tung, 2007). Nevertheless, certain interesting and relevant issues remain to be addressed, such as the influence of the host-country investment climate (economic institutions) on the cross-border location decisions of EMBGs.

Along these lines, this study contributes to literature in several ways. First, by drawing on foreign direct investment theory, it builds upon the New Institutional Economics (NIE) framework (North, 1990; Scott, 2001; Grosse and Trevino, 2005) that provides a more comprehensive theoretical setting through which to investigate empirically how economic institutions

1 According to recent statistics, the global share of OFDI from emerging economies increased from $34 \%$ in 2005 to $51 \%$ in 2011 . Although the global financial crisis caused a significant decline, the share of OFDI is expected to gain further momentum in coming years (UNCTAD, 2012).

2 A multinational business group is composed of every multinational that controls at least one foreign affiliate through formal ownership linkages (Keister, 1998; Altomonte and Rungi, 2013). 
influence the OFDI location decisions of EMBGs. The NIE framework highlights how economic institutions affect transaction costs based on the investment risks and uncertainties in host countries (North, 1990; Dunning 2010). As the costs of foreign entry are arguably high for EMBGs, the relevance of institutional environments becomes more important in examining their OFDI activities.

Second, in contrast to most current research on OFDI from emerging economies that concentrates on large Asian countries (Sauvant, 2005), this study focuses on the emerging economies of the European Union (EU). Different organizational forms from Central and Eastern European Countries (CEECs) are becoming increasingly integrated into regional and global businesses through OFDI, particularly after their respective countries have become members of the EU (Jaklič and Svetličič, 2003). Additionally, in contrast to existing investigations on the subject (see Pye, 1998; Devereux and Griffith, 1998; Grosse and Trevino, 2005; Botrić and Škuflić, 2006; Tintin, 2013), this study does not focus on one or multiple CEECs nor on inward investments to these countries. Instead, it analyzes the determinants of the OFDI location choices for all the CEECs that joined the EU in 2004 and 2007.3 This study thus provides original empirical insights that specifically explain how various institutional factors influence the OFDI location decisions of European EMBGs.

Third, the study contributes to contemporary evidence by examining the OFDI location decisions of EMBGs in both emerging (i.e., CEECs) and advanced economies (i.e., EU15) $\left.\right|^{4}$ Multinational organizations from emerging economies investing in advanced economies have received considerable attention from scholars (Gammeltoft, 2008; Ramamurti and Singh, 2009). Only recently, however, have researchers begun to empirically examine various aspects of this new phenomenon. Hence, this study systematically investigates and compares the influences of the institutional environments of advanced and emerging economies on the location choices of EMBGs.

Finally, this study analyzes how the relative institutional differences between source (home) and destination (host) countries interplay with the location decisions of CEEC investors. In this way, it contributes to the debate on the impact of "institutional difference" on OFDI activities (e.g., Kostova, 1996; Bénassy-Quéré et al., 2007) and extends, as far the data allow, the analysis of institutional differences by distinguishing the effects of common borders and firm-specific heterogeneities.

3 The EU analysis is based on the rationale that the initial international expansion of firms is concentrated regionally (Johanson and Vahlne, 1977), which is particularly the case for CEEC firms. These firms are new players in international business and only a small share $(0.83 \%)$ of OFDI from CEECs leaves the EU (EUROSTAT, 2012).

4 EU15 is the number of member countries prior to the largest enlargement of the EU on 1 May 2004, and CEECs comprise new member states of the EU excluding Croatia, Cyprus and Malta (OECD Glossary of Statistical Terms, 2007). A list is provided in Table 1A (in the Annex). 
With regard to the selection of institutional factors, scholarly agreement is inconclusive because of the analytical difficulties in measuring and defining institutional effects. However, previous empirical investigations have identified several factors that influence the cross-country OFDI location decisions of foreign investors, notably focusing on the interaction between institutions and multinational organizations from advanced economies or on inward investments in emerging economies. For instance, property rights protection, direct/indirect taxation, persistent bureaucratic ramifications, corruption, business regulatory environments (rules for opening, closing and financing businesses) and monetary controls in host countries are all associated with OFDI location activities (Disdier and Mayer, 2004; Cassou, 1997; Devereux and Griffth, 1998; Wei, 2000; Hoskisson et al., 2000; Cotton and Ramachandran, 2001; Lankes and Venables, 1996). Therefore, in addition to conventional OFDI location determinants, this study uses a number of indices that reflect the institutional strength of host countries (as sources of comparative advantages) in terms of property rights protection, the level of corruption, national taxation, business regulations and macroeconomic stability.

Empirically, this study utilizes firm-level data (Greenfield OFDI projects of EMBGs) on a set of investors from the 10 emerging economies of the EU (Bulgaria, Czech Republic, Estonia, Hungary, Latvia, Lithuania, Poland, Romania, Slovakia and Slovenia) from 1995 to 2010. The estimation results are obtained by using a discrete choice maximum likelihood procedure within the framework of the utility maximization approach (McFadden, 1974).

The remainder of this paper proceeds as follows. The next section provides the theoretical background and formulates the hypotheses. Section 3 discusses the data and variables used in this study. Section 4 explains the econometric methodology adopted. Section 5 reports and discusses the results, and section 6 concludes.

\section{Theory and Hypotheses}

\subsection{Theoretical Background}

The literature on the ongoing internationalization of EMBGs shows a variety of approaches such as the institutional approach, market-centered theory and the resource-based view (Yang et al., 2009).5 Collectively, these

\footnotetext{
${ }^{5}$ According to the literature review provided by Yaprak and Karademir (2010), marketcentered theory emphasizes the role of market imperfections (e.g., market failures, oligopolistic reactions, competitive rivalry) in the formation of EMBGs; the institutional approach links the home-country institutional environment (e.g., influences of formal and informal institutional arrangements, institutional voids, supporting role of home governments, social networks) to the organizational embodiments of EMBGs; and the resource-based view takes into account the local and international adaptabilities (e.g.,
} 
studies point to the critical significance of the various home-country circumstances that may lead to the organic formation of EMBGs and the subsequent procurement of their organizational capabilities to internationalize, with little or no focus on the relevance of the role played by hostcountry factors on affecting the cross-border entry procedures of investors from emerging economies. Indeed, scholars have only recently realized the possible implications of mainstream foreign direct investment theory for the foreign entry strategies and location activities of EMBGs (e.g., Yaprak and Karademir, 2010).

While the conventional theory provides a rich theoretical foundation, the complexity of OFDI dynamics makes it difficult to analyze location determinants under a unified analytical framework. ${ }^{6}$ By drawing upon previous theories of international expansion, 7 the eclectic paradigm of Dunning (1977, 1979, and 1988) highlights the location determinants pertaining to the interactions of the Ownership, Location and Internalization (OLI) advantages of multinational organizations. Dunning's paradigm emphasizes rational profit-seeking OFDI decisions on the part of investors in terms of existing endogenous (firm-specific) and exogenous (location-specific) advantages. On the one hand, endogenous attributes such as sophisticated production, innovation and commercial competences enable investors to exploit their competitive advantages given market asymmetries. The intrinsic attributes of host locations (e.g., market potential, infrastructure, natural resources), on the other hand, facilitate the successful implementation of firms' key strategic OFDI motives.8 Therefore, the ensuing returns that emerge from the synergies of OLI advantages actuate market-oriented OFDI in a particular country rather than exporting or licensing.

Although the underlying assumptions of the eclectic paradigm have been demonstrated to be robust across the intricacies of OFDI location activities, they are considered to be too broad for a full analytical implementation and lack a uniform formalization in different settings (Buckley and Hashai, 2008). In particular, Dunning's paradigm focuses on the OLI capabilities of foreign entrants in market-bound macroeconomic environments to gain economic efficiency in host countries through firm-market interactions, while lacking extra-market institutional content considered being essential for such interactions (Dunning, 1993; Sethi et al., 2002; Scott, 1995,

organizational and experiential learning, preferential access to resources) of EMBGs.

6 See Faeth (2009) for a detailed review of foreign direct investment theory in international business.

7 The eclectic paradigm (as its name suggests) broadly advances the contributions of earlier international business researchers (e.g., Caves, 1971; Hymer, 1976; Buckley and Casson, 1976).

8 Building upon OLI, Dunning's taxonomy of investment motives (Dunning, 1988, 1993) includes market-seeking, resource-seeking, efficiency-seeking and strategic asset-seeking OFDI. 
2001).9 9

By contrast, the NIE approach, which links the economic institutions (e.g., property rights protection, corruption, taxation, business regulatory provisions, economic stability) of host countries with the economic efficiencies of investing firms, has been developed in accordance with the relevance of the "regulative" element of general institutional theory. ${ }^{10}$ This regulative element consists of the legal provisions and rules defined by government regimes that oversee economic activities (Scott, 2001). The particular focus of the NIE approach is on the intersection of formal institutional provisions and operating firms that arise from the market imperfections that shape the investment behaviors of foreign entrants (Harris et al., 1995; Oliver, 1997).

According to North (1990), institutions are essential for market dynamics as they set the "rules of the game" for economic activities. An investment friendly and market-supporting institutional environment facilitates foreign investors by eliminating or reducing unnecessary hurdles in business operations and maintaining such activities in host locations (Estrin et al., 1997; Wei, 2000, Henisz, 2000; Mudambi and Navarra, 2002). Foreign entrants are likely to reduce transaction costs and maximize profits in the presence of well-functioning regulatory frameworks and market supporting policies (Hoskisson et al., 2000; Daude and Stein, 2007). Thus, a favorable and efficient market-supporting institutional regime reduces investmentrelated costs of foreign investors in uncertain business environments and does not hinder access to important organizational capabilities (North, 1990, 1991; Wheeler and Mody, 1992; Hoskisson et al., 2000; Wei, 2000; Grosse and Trevino, 2005; Guillén, 2000).

The institutional factors (investments, governance and business regulatory systems) of a host country become even more important for the international relocation activities of EMBGs. They are widely considered to be fundamentally different from their counterparts in advanced economies in several firm- and country-specific features (Ramamurti and Singh, 2009). For instance, they emerge from highly imperfect markets with lower levels of technological and institutional development. In contrast to firms from advanced economies, these firms generally lack the resources necessary to optimally offset the costs of foreign entry. ${ }^{11}$ Thus, these organizations are more

\footnotetext{
9 Dunning himself acknowledged the lack of institutional aspects in his original paradigm and extended his research accordingly in later studies (Dunning, 2010, 2006; Dunning and Lundan, 2008).

${ }^{10}$ Institutional theory identifies three key elements of the socioeconomic institutional environment: the cultural-cognitive (e.g., socially shared beliefs and expectations), the normative (e.g., socially shared identities and frameworks for mutual values/interests) and the regulative (e.g., formal/official regulations and laws) elements (Scott, 1995, 2001).

${ }^{11}$ A number of international business scholars have discussed the different characteristics of firms from emerging economies and their diverse internationalization strategies (see, among others, Mathews, 2002, 2006; Luo and Tung, 2007; Peng et al., 2008; Ramamurti, 2009, 2012).
} 
exposed to the risks and uncertainties associated with investments in new locations, notably in countries with weak institutions (Meyer, 2001). EMBGs from the emerging economies of the $\mathrm{EU}$, in particular, may be more responsive to institutional aspects because of their unique backgrounds compared with other emerging economy multinational organizations. These organizations originate in countries that are undergoing significant structural, economic and institutional transformations in the post-communist period. Unlike multinational organizations from other emerging economies, they are relatively new in the international business environment, and therefore they contain weaker ownership characteristics and have inherited centralized infrastructures that limit their international expansion capabilities (Svetličič and Jaklič, 2003; Meyer, 2001). These observations might suggest that the OFDI location activities of European EMBGs are more prone to be influenced by the host-country institutional environments, which can be related to their limited experience and resources in overcoming the costs associated with investment uncertainties.

\subsection{Hypothesis Development}

\subsubsection{Property Rights Protection}

The protection of property rights in terms of the efficient enforcement of contracts and reduced government intervention is considered to be an important institutional determinant of OFDI location decisions (Smith, 1976; Cotton and Ramachandran, 2001). Foreign investors are interested in the proper enforcement of legal contracts to ensure continuous business transactions. The extent of government participation in such enforcement is thus crucial, as a higher level of government intervention in executing and implementing business contracts reduces the liberty of investing organizations in their economic activities in host countries. Contractual activities are often executed among private entities within a supply value chain (North, 1991; Porter, 1985). However, this notion also extends to the contractual activities between government and private entities (North and Weingast, 1989; Barro, 1996; Olson, 2000). In either case, foreign investors prefer the presence of a higher level of property rights protection because of their limited ethnic and cultural ties in host countries (Kostava and Zaheer, 1999). Moreover, the "foreignness" attributes of investors increase the costs of "exit" in the case of the weak enforcement of contracts among business entities and/or bureaucratic hurdles imposed by governments for acquiring or disposing of assets. Hence, investors prefer to establish affiliates in countries where contract enforcement is overlooked by independent judiciaries and where bureaucracy exists with limited government interventions. Thus, CEEC investors may be likely to choose a country with greater prospects for private property accumulation and preservation where the government's guaran- 
tee for property rights protection is indicated through an efficient judiciary system that enforces contractual arrangements with minimum government expropriation. Therefore, the following hypothesis is posited:

Hypothesis 1: CEEC investors are more likely to locate their affiliates in countries that offer better property rights protection.

\subsubsection{Corruption}

Corruption is another factor that may drastically affect the efficiency of OFDI activities. It arises from the misuse of discretionary authority, unchecked or endorsed by weak legal systems in host countries (Jain, 2001). The omnipresence of corruption in destination countries is widely believed to affect business operations through improper policy conduct and regulatory contraventions, consequently increasing the operating costs of foreign investors (Bardhan, 1997; Jain, 2001). The existing literature predominantly suggests the negative effects of prevailing corruption in host countries on the prospects of OFDI with some exceptions. ${ }^{12}$ As underscored previously, EMBGs are noted for their limited capabilities of resources allocations in foreign countries, and therefore they may have higher sensitivities to the risks and costs of OFDI activities in corrupt countries, as demonstrated by recent studies (Hines, 1995; Wei, 2000; Grosse and Trevino, 2005). Along these lines the OFDI activities of CEEC investors should be discouraged by the preponderance of corruption in host economies. Thus:

Hypothesis 2: CEEC investors are more likely to locate their affiliates in less corrupt countries.

\subsubsection{Taxation}

The higher imposition of direct and indirect taxes increases the transaction costs of establishing and maintaining businesses in foreign countries (de Mooij and Ederveen, 2001). Indeed, several studies in the European context suggest that intra-EU trade is more responsive to the differences in tax rates in host countries. Among different types of taxes imposed in host countries, Devereux and Griffith (1998) show a negative relationship between effective tax rates and OFDI location decisions of U.S. multinationals in Europe. Similarly, on the effects of corporate income taxation, most EUbased studies find a negative effect of higher tax rates on OFDI. For instance, Bellak and Leibrecht (2009) use panel gravity model settings to analyze the effect of corporate taxation on OFDI and find a negative relationship, especially in CEECs. Gorter and Parikh (2003), in their study of OFDI location activities in Europe find a negative relationship, depicting a $4 \%$ increase in

\footnotetext{
${ }^{12}$ Some earlier empirical investigations, such as that of Wheeler and Mody (1992), find that host-country corruption does not significantly influence foreign investment activities.
} 
OFDI following a $1 \%$ decrease in effective corporate tax. Considering the empirical evidence, a higher level of overall fiscal burden in a host country is expected to increase the cost of business and reduction in profit, thus decreasing the likelihood of OFDI being located there. Thus, the following is asserted:

Hypothesis 3: CEEC investors are more likely to locate their affiliates in countries with reduced tax burdens.

\subsubsection{Business Regulations}

Business regulations that ease operations can be an important influencing factor of OFDI location decisions. The level of difficulty in starting a business or the time it takes to establish and operate affiliates in host countries may affect foreign investors adversely. Moreover, liberal financial governance and limited government control on financial institutions in host countries may provide investing firms with increased certainty and financial security. However, the difficulties involved in measuring business regulations have continuously hampered the systematic analysis of their influence on OFDI location activities. The limited evidence suggests that the time it takes to start a business in a host country and the regulations on supply mechanisms affect the location choices of foreign investors (Djankov et al., 2002; Botero et al., 2004). Furthermore, established financial infrastructure and access to local capital reduces foreign investor's exposure to exchange rate risks in host countries (La Porta et al., 1997; Bevan et al., 2004; Djankov et al., 2008). Given the constrained resources of foreign entrants from emerging economies, it may be argued that CEEC investors are particularly interested in locations with an efficient regulatory environment for business activities and local financial sourcing. Indeed, the transaction costs incurred upon them in the establishment and shutdown of business activities may increase with a complicated set of operating and financial regulations in the destination countries. Therefore:

Hypothesis 4: CEEC investors are more likely to locate their affiliates in countries with favorable business and financial regulations.

\subsubsection{Economic Stability}

Inefficient monetary governance in the host economy imposes a high risk on foreign investors owing to the presence of higher inflation rates and weak price control mechanisms (Meyer, 1998, 2001). Excessive money supply triggers a higher rate of inflation and disturbs market activities in terms of increased transaction costs because of the higher level of input prices. As a result, a lower level of economic competition may arise, thus disrupting market dynamics and impeding further investments. Inconsistent monetary policies in host countries also increase the costs attached to 
local sourcing, capital budgeting and strategic planning, subsequently decreasing profitability (Meyer, 2001; Grosse and Trevino, 2005). A number of empirical investigations have examined how economic stability affects the location dynamics of OFDI (Blonigen, 2005). The rate of inflation has been used as a somewhat conventional measure of economic stability, with higher inflation rates suggesting a lower level of stability. For instance, the survey carried out by Lankes and Venables (1996) among European investors finds macroeconomic stability to be an important determinant because it helps measure the risks of investment attached to OFDI in a particular country. Similar findings are reported by Trevino et al. (2002) and Clausing and Dorobantu (2005) for the relationship between inflation and foreign investments in Latin American and CEECs, respectively. Because the empirical evidence points to a positive relationship between efficient monetary management in host countries and inward investment, the following is posited for CEEC investors:

Hypothesis 5: OFDI location choices from CEEC investors are positively affected by the macroeconomic stability of host countries.

\subsection{Data and Variables}

\subsubsection{Data Description}

The firm-level data on OFDI projects in the EU come from Bureau van Dijk's AMADEUS database (online version 2012).13 The data consist of foreign affiliates owned by investors (headquarters/parent in a multinational business group) located in the 10 emerging economies of the EU (Bulgaria, Czech Republic, Estonia, Hungary, Latvia, Lithuania, Poland, Romania, Slovakia and Slovenia). ${ }^{14}$ The observed time period is 1995-2010 because the data on many of the independent variables were unavailable before 1995.

One of the main advantages of this dataset is the ability to observe directly the country of origin and country-level cross-sectional distribution of the foreign affiliates owned by EMBGs in both the emerging economies and the advanced economies of the EU. In this study, owing to data limitations, it was not possible to include detailed firm-specific control information. However, given that the data contain a year of entry, industrial sector and investor size for each firm, it is possible to link these cross-sectional

${ }^{13}$ AMADEUS is a European database of comparable activities for both public and private companies. It contains comprehensive information on around 19 million companies. This study, however, only takes into account foreign affiliates of EMBGs located in the then 27 member states of the EU.

${ }^{14}$ An "investor" is the ultimate owner/major shareholder of an affiliate located in one of these CEECs. It is defined as either a direct shareholder with a minimum of $10 \%$ equity in the host-country affiliate or the ultimate owner with a minimum of $25 \%$ indirect ownership. 
data to the time-series information of various host-country-specific location determinants, namely the variables associated with the institutional environments of host countries and those traditionally associated with OFDI location decisions across countries.

In the dataset, 1,313 EMBGs from CEECs were identified to have had affiliates in the EU between 1995 and 2010. Of these, 1,036 EMBGs were from EU member states that invested in other members. Table 2A (in the Annex) shows that the majority (58\%) of EMBGs from CEECs invest in other CEEC economies, whereas the remaining $42 \%$ invest in EU15. EMBGs from the Czech Republic (33.5\%) and Poland (29.6\%) own the highest number of affiliates, followed by Estonia (7.7\%), Lithuania (7.1\%) and Slovakia (6.1\%). Investors from the relatively new member states of Bulgaria and Romania own a smaller share of affiliates in the sample (1.4\% and $1.5 \%$, respectively). However, this trend also extends to the states that have been members the longest, as $3.1 \%$ of affiliates are owned by Slovenian and $5.1 \%$ by Hungarian investors.

The largest OFDI destinations are Great Britain (19.5\%), Slovakia (18.5\%) and Germany $(10.5 \%)$. It is also evident that Great Britain is home to the largest share of affiliates in the EU15, with parent organizations of EMBGs mainly located in Poland. Another interesting feature is that most foreign affiliates based in Slovakia have Czech owners, while affiliates based in the Czech Republic are owned by Slovakian EMBGs. In addition, Table 2A also shows that the majority of OFDI from CEECs targets neighboring countries, suggesting that OFDI from CEECs is mainly driven by geographical and historical proximities.

The industrial distribution of the data is analyzed by using European industrial classifications (i.e., NACE) ${ }^{15}$ One limitation in this regard is the aggregated distribution of industrial sectors (manufacturing and services) in the sample due to limited firm-specific information, which did not allow for an in-depth investigation of the types of OFDI under study. ${ }^{16}$ Table 1 presents the distribution of OFDI among the different industrial sectors in both source and destination countries. The majority of investments from CEEC investors come from the same sector, supporting the argument proposed by several studies that international OFDI activities are dominated by horizontal OFDI (e.g., Brainard, 1997; Markusen and Maskus, 2002; Yeaple, 2003). Moreover, vertical OFDI is also apparent, if not dominant, in the sample. Generally, OFDI distribution supports the studies that consider OFDI activities to mainly be a mixture of horizontal and vertical direct investments (Markusen and Venables, 2007).

\footnotetext{
15 The statistical classification of economic activities in the European community, Nomenclature statistique des activités économiques dans la Communauté européenne, which is generally referred to as NACE, is the European equivalent of NAICS (the North American Industrial Classification System), consisting of up to four digits of industrial classification.

${ }^{16}$ Owing to the small sample size, the present study uses the first two digits of NACE (Revision.2) to divide the sample into manufacturing and service sectors.
} 
Table 1 - Share of Horizontal and Vertical OFDI in the Sample

\begin{tabular}{lc}
\hline \multicolumn{1}{c}{ Industrial classification } & Share in total sample \\
\hline Manufacturing (parent) - Manufacturing (affiliate) & $8.35 \%$ \\
Manufacturing (parent) - Services (affiliate) & $36.90 \%$ \\
Services (parent) - Manufacturing (affiliate) & $3.76 \%$ \\
Services (parent) - Services (affiliate) & $50.99 \%$ \\
Total & $100.00 \%$ \\
\hline
\end{tabular}

Source: Own calculations based on AMADEUS database (2012)

Figure 2 displays the yearly distribution of the foreign affiliates of CEEC investors in the EU, which confirms the generally increasing trend in OFDI from emerging economies, without a significantly large variance until 20072008. However, a decline in investments after 2008 can be observed, which seems to be a clear result of the global financial crisis. Furthermore, the gradual upward trend from 2004 depicts the increased entry of CEEC investors in general, as eight out of the 10 CEECs studied herein became members of the EU in 2004.

Figure 1 - Annual Entry Rates of EMBGs' Affiliates in the EU

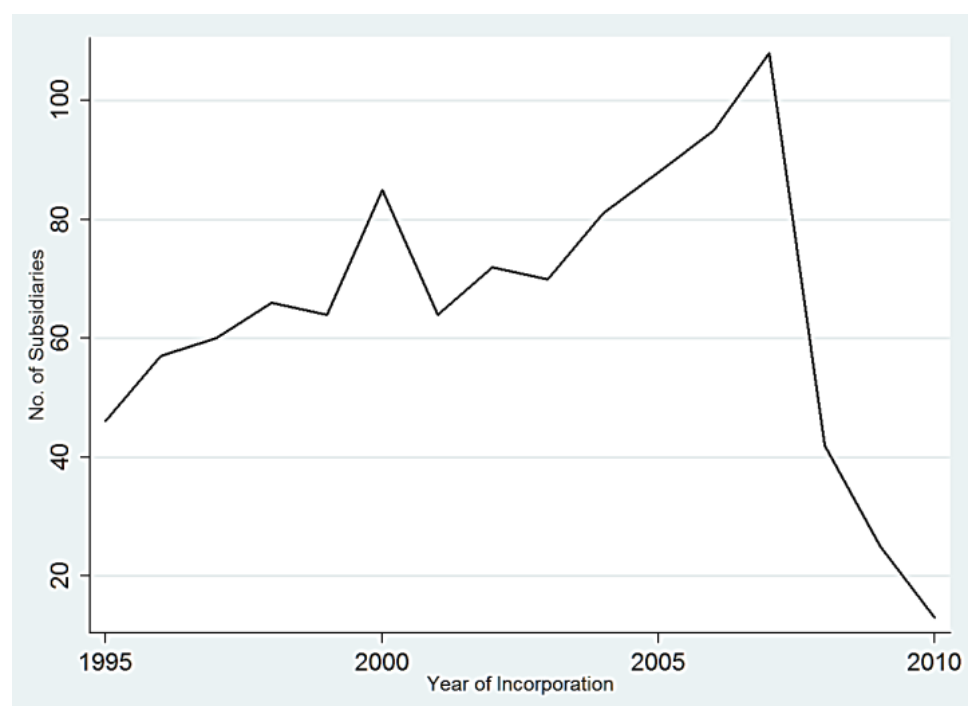

Source: Own calculations based on AMADEUS database (2012)

\subsection{Variables}

\subsubsection{Dependent Variable}

The dependent variable (CHOICE) is a binary variable of the location choice (entry of a foreign affiliate) in a particular country by a CEEC investor 
from a subset of 26 possible other host countries in the EU.

\subsubsection{Institutional Variables and Measurements}

The measurement of institutional variables has been disputed among researchers, leading to rather controversial results. The difficulties in the measurement of economic institutions have led several researchers to adopt macroeconomic policy variables (inflation rates, taxation) as proxies of institutional quality (e.g., Bellak and Leibrecht, 2009). In addition to macroeconomic variables, some researchers have emphasized the importance of formal regulatory provisions in host locations for foreign entrants (e.g., Lim, 2001), thus leading to the use of different ranking-based indices in OFDI location studies, particularly in gravity model settings (e.g., Tintin, 2013). However, using such an index as a measurement of institutional quality has drawn some criticism because of its perception-based computation and the possibility of high correlations with other institutional indices (La Porta et al., 1999).

Because this study examines the effects of economic institutions on the location decisions of firms and investors rather than on OFDI flows/stocks, ${ }^{17}$ it can be argued that locations (countries) are selected on the perceptions of the individual investor subjected to the returns associated with the investment in a particular host country. Therefore, this study uses the annual indices of economic freedom (1995-2010) provided by the Heritage Foundation (HF). The availability of such a large time-series dataset, firm-level observations $(24,726)$ and intra-country analysis reduces the issue of possible idiosyncratic correlations and allows the analysis of data in both time and cross-sectional dimensions. A detailed list of the variables, sources and measurements is given in Table 2 .

Property rights protection

In the analysis, the HF's index of property rights protection (PP) is used as a proxy of the state of property rights protection in host countries. The index reflects the extent to which the government of the host country guarantees property rights against the unlawful confiscation/closure of private property and provides legal regulations for entry/exit-related contractual activities.

\section{Freedom from corruption}

The HF's index of freedom from corruption (CF) represents the extent of corruption in the host country. This index is based on Transparency International's corruption perception index.

${ }^{17}$ Traditional empirical investigations of the location determinants of OFDI adopt the bilateral flows or stocks of OFDI as a measure of foreign investment activities, for example, in the context of gravity modeling. However, these measures have been subject to some criticism in recent studies, as they do not explain the decision-making process of investors (Beugelsdijk et al., 2010). 
Table 2 - Variable, Symbols and Measurements

\begin{tabular}{|c|c|c|}
\hline Variables & Symbols & Type \& Measurement \\
\hline \multicolumn{3}{|l|}{ Dependent Variable } \\
\hline Choice & CHOICE & $\begin{array}{l}\text { Binary (0-1) Location choice from a set of } 26 \text { alternative } \\
\text { countries within the European Union }\end{array}$ \\
\hline \multicolumn{3}{|l|}{ Independent Variables } \\
\hline Property right protection & PP & $\begin{array}{l}\text { Index }(0-100), 0-\text {-no property right protection, } 100 \text {-full property } \\
\text { right protection* }\end{array}$ \\
\hline Freedom from corruption & $\mathrm{CF}$ & $\begin{array}{l}\text { Index(0-100), 0-no freedom from corruption, } 100 \text {-full freedom } \\
\text { from corruption* }\end{array}$ \\
\hline Fiscal freedom & $\mathrm{FF}$ & Index (0-100), 0- no fiscal freedom, 100 - full fiscal freedom* \\
\hline Business freedom & $\mathrm{BF}$ & $\begin{array}{l}\text { Index (0-100), 0-no business freedom, } 100 \text {-full business } \\
\text { freedom* }\end{array}$ \\
\hline Financial freedom & FiF & $\begin{array}{l}\text { Index (0-100), 0-no financial freedom, 100-full financial } \\
\text { freedom* }\end{array}$ \\
\hline Monetary freedom & MF & $\begin{array}{l}\text { Index (0-100), 0-no monetary freedom, 100-full monetary } \\
\text { freedom* }\end{array}$ \\
\hline \multicolumn{3}{|l|}{ Control Variables } \\
\hline Market size & MKTSIZE & Log Annual GDP per capita of the host country (000s) ${ }^{* * *}$ \\
\hline Market growth & MKTGROWTH & $\%$ age, Log Annual GDP growth of the host country*** \\
\hline Research endowments & $R \& D$ & $\%$ age, share of GDP dedicated to Research \& Development*** \\
\hline Skilled labor & HRSTO & $\begin{array}{l}\text { Log Human Resource in Science and Technology(000s) in the } \\
\text { host country** }\end{array}$ \\
\hline Land & PDENS & $\begin{array}{l}\text { Log People per square } \mathrm{km} \text { of land area (00s) in the host } \\
\text { country*** }\end{array}$ \\
\hline Infrastructure & INF & Log $\%$ of paved roads in total roads of the host country** \\
\hline Proximity & PROXIMITY & $\begin{array}{l}\text { Log Euclidean distance in km between capital of home country } \\
\text { and the alternative's**** }\end{array}$ \\
\hline
\end{tabular}

Sources $(2012,2013):$ *Heritage Foundation, ${ }^{\star \star}$ Eurostat, ${ }^{* \star *}$ World Bank, ${ }^{* * \star *}$ Own calculations, time-series (19952010) 


\section{Fiscal freedom}

HF's index of fiscal freedom (FF) measures the burden of direct and indirect taxes on operating businesses in the host countries (e.g., corporate tax, income tax, and top marginal tax).

\section{Business regulations}

This study uses two indices to measure the regulatory provisions that administer business operations. First, the HF's index of business freedom $(\mathrm{BF})$ is derived from the time consumption and difficulty involved in starting and licensing new businesses in the host country. Second, the index of financial freedom $(\mathrm{FiF})$ represents the extent of government intervention in financial activities and banking efficiency in securing financing.

\section{Monetary freedom}

The level of economic stability in host countries is measured by using the HF's index of monetary freedom (MF). This index is established by using weighted averages of the price stability and inflation rate in the host country.

\subsubsection{Control Variables}

In the analysis, unbiased estimations are ensured by using a number of control variables widely believed to affect OFDI location decisions (Blonigen, 2005). Traditional OFDI theory has highlighted the influence of the host-country's market in attracting market-seeking investments (Dunning, 1977, 1993; Coughlin et al., 1991). Thus, in order to account for the market strength of the host country, this study uses the GDP per capita of the host country as a proxy of market size (MKTSIZE) and annual GDP growth rate as a proxy of the host country's market growth (MKTGROWTH).

Scholars have further emphasized the particular relevance of knowledgeseeking OFDI for EMBGs (Mathews, 2006; Luo and Tung, 2007). Thus, this study controls for the knowledge- and technology-related aspects of the host country by measuring total research endowment expenditure as a percentage of GDP (R\&D) and total skilled labor/human resources in science and technology occupations (HRSTO). Higher spending on research by a country indicates priority given to knowledge generation activities, whereas the availability of skilled labor reflects the knowledge stock in the host country.

Additionally, two variables control for the efficiency-related aspects of the host country. Population density (PDENS) is used to reflect land prices and the availability of commercial property related to urbanization, while communication infrastructure (INF) is presented as the percentage of paved roads relative to the total roads in a particular country, which agrees with previous studies of the location choice (Biswas, 2002; Asiedu, 2006). Finally, geographical proximity (PROXIMITY) measures the distance between the capital cities of the source and destination countries. Geographical proximity is considered to be an important location determinant that is associated 
with internal organizational transactions, reduction in operating costs and investment risks in new locations (Disdier and Mayer, 2004; Bevan and Estrin, 2004).

\section{Methodology}

This study explores its hypotheses using a simplified model of the decision-making process among CEEC investors (see Devereux and Griffith, 1998; Basile et al., 2008). The main assumptions of this model can be expressed in three steps:

(1) An investor (a CEEC multinational business group) decides to invest in another market.

(2) The investor decides the most appropriate medium of internationalization (e.g., export, OFDI).

(3) The investor chooses a market for future investment by using the most relevant type of investment (OFDI in this analysis).

This paper directly addresses the third step of this model, in which a country is chosen by a CEEC investor over other countries in the EU based on certain advantages of the chosen host country. It is assumed that such selection by a CEEC investor depends on the expected profitability perceived - and the potential benefits offered by — the host country. The potential benefits are identified by means of the comparative advantage of one country over alternative countries and are associated with the country's investment environment (location-specific institutional factors) for OFDI. Moreover, country-level institutional determinants are assumed to be uniform across all the alternative countries in the EU. Furthermore, it is assumed in this analysis that the investment decision was made one year before the actual investment because the failure to do so would create an endogeneity issue, i.e., the foreign affiliate's investment may potentially affect the explanatory variables through its own activity.

To empirically test the theoretical model presented, the random utility maximization approach provides a reasonable basis for obtaining reliable empirical results (Guimarães et al., 2004). The random utility maximization framework has been extensively used in studies on firm-level location choice since McFadden (1974) first proposed the framework. This framework accounts for the assumption that the evaluation of a decision maker (the investor in this analysis) among available alternatives (countries in this analysis) can be represented by an expected utility (profit) function through a maximum likelihood procedure.

Applying the model specified by Guimarães et al. (2004) at the country level, the model assumes the existence of $j$ choices among EU countries 
with $\mathrm{j}=1, \ldots, \mathrm{j}$ and $N$ investors with $\mathrm{i}=1, \ldots \ldots, \mathrm{N}$. Thus, the profit derived by investor $i$ by locating in country $j$ is given by

$$
\pi_{i j}=\beta^{\prime} z_{i t}+\epsilon_{i j}
$$

where $\beta$ is a vector of unknown parameters, $z_{i j}$ is a vector of observed explanatory variables, and $\epsilon_{i j}$ is a random term. Thus, the profit of investor $i$ for locating in country $j$ is composed of a deterministic and a stochastic component. The investor will choose the country that will yield the highest expected profit. If the $\epsilon_{i j}$ are independently and identically distributed (iid) ${ }^{18}$ it can be shown that

$$
P_{i j}=\frac{e^{\beta^{\prime} z_{i j}}}{\sum_{j=1}^{J} e^{\beta^{\prime} z_{i j}}}
$$

where $P_{i j}$ is the probability that investor $i$ locates in country $j$. If $\mathrm{d}_{i j}=1$ in case investor $i$ picks choice $j$, and $\mathrm{d}_{i j}=0$ otherwise, then the log likelihood of the conditional logit model can be represented as:

$$
\log L_{c l}=\sum_{i=1}^{N} \sum_{j=1}^{J} d_{i j} \log P_{i j} .
$$

Along these lines, the conditional logit regression model for the expected profit $\left(\pi_{i j}\right)$ of a CEEC investor is specified as:

$$
\begin{aligned}
& \pi_{i j}=\beta_{1} P P_{j t_{i-1}}+\beta_{2} C F_{j t_{i-1}}+\beta_{3} F F_{j t_{i-1}}+\beta_{4} B F_{j t_{i-1}}+\beta_{5} F i F_{j t_{i-1}}+ \\
& \beta_{6} M F_{j t_{i-1}}+\beta_{7} M K T S I Z E_{j t_{i-1}}+\beta_{8} M K T G R O W T H_{j t_{i-1}}+ \\
& \beta_{9} R \& D_{j t_{i-1}}+\beta_{10} H R S T O_{j t_{i-1}}+\beta_{11} P D E N S_{j t_{i-1}}+\beta_{12} I N F_{j t_{i-1}}+ \\
& \beta_{13} \text { PROXIMITY }{ }_{j}+\epsilon_{i j} \text {, }
\end{aligned}
$$

where the parameters $\beta_{1}$ to $\beta_{6}$ constitute the institutional variables related to the main hypotheses discussed in Section 2 , and $\beta_{7}$ to $\beta_{13}$ constitute control variables for country-specific location choice.

Additionally, the existing literature suggests that institutional differences among countries can be sources of comparative advantages for OFDI location activities (Levchenko, 2004; Habib and Zurawicki, 2001; Bénassy-Quéré et al., 2007). Therefore, another specification is drawn to model the effects of institutional differences (between source and destination country) on the expected profitability of a CEEC investor:

$$
\begin{aligned}
& \pi_{i j}=\beta_{1} \Delta P P_{j t_{i-1}}+\beta_{2} \Delta C F_{j t_{i-1}}+\beta_{3} \Delta F F_{j t_{i-1}}+\beta_{4} \Delta B F_{j t_{i-1}}+\beta_{5} \Delta F i F_{j t_{i-1}}+ \\
& \beta_{6} \Delta M F_{j t_{i-1}}+\beta_{7} M K T S I Z E_{j t_{i-1}}+\beta_{8} M K T G R O W T H_{j t_{i-1}}+ \\
& \beta_{9} R \& D_{j t_{i-1}}+\beta_{10} H R S T O_{j t_{i-1}}+\beta_{11} P D E N S_{j t_{i-1}}+\beta_{12} I N F_{j t_{i-1}}+ \\
& \beta_{13} P R O X I M I T Y_{j}+\epsilon_{i j},
\end{aligned}
$$

${ }^{18}$ The critical assumption holds that the unobserved factors are uncorrelated over alternatives, as well as having the same variance for all alternatives. This assumption, while restrictive (independence of irrelevant alternatives), provides convenient modelling of choice probability (Train, 2003). 
where the parameters $\beta_{1}$ to $\beta_{6}$ constitute the relative differences between the institutional quality of the home and host countries i.e., the index ranking difference between the country of investor and the country where OFDI takes place.

Furthermore, a body of scholars has argued that EMBGs may perform better in markets that are geographically, institutionally and culturally similar to their home-countries than the unfamiliar markets (e.g., Johanson and Vahlne, 2009; Helpman et al., 2008; Guiso et al., 2009). Also, investor's firmspecific characteristics have been associated with the location strategies of foreign investors, such as firm size and industrial organization (Helpman, 1984; Dunning, 1993; Porter, 1985).

Therefore, under the assumption that the characteristics of investors affect the evaluation of their location choices, the interaction effects of border and firm-specific heterogeneities are introduced in the baseline specification (2) corresponding to the main exogenous variables and in line with the key hypotheses of this study:

$$
\pi_{i j}=\beta^{\prime} z_{i j}+\gamma^{\prime} \text { Borderdum }_{i} \times v_{i j}+\delta^{\prime} \text { Sectordum }_{i} \times v_{i j}+\varepsilon^{\prime} \text { Sizedum } \times v_{i j}+u_{i j}
$$

where $\beta$ is a vector of unknown parameters, $z_{i j}$ is the vector of the observed explanatory variables specified in specification (2), $\gamma$ is a vector of the unknown parameters from the interaction between Borderdum $m_{i}$ and $v_{i j}$ a vector that contains a linear combination of all exogenous variables (institutional differences), $\delta$ is a vector of the unknown parameters from the interaction between Sectordum $_{i}$ and $v_{i j}, \varepsilon$ is a vector of the unknown parameters from the interaction between Sizedum ${ }_{i}$ and $v_{i j}$, and finally, $u_{i j}$ is a random term.

Borderdum $_{i}$ represents a dummy variable that equals one if the respective affiliate of investor $i$ is located in the bordering country of the investor's country and zero otherwise. This dummy is expected to observe the effects of institutional difference while EMBGs locate their affiliate in countries which are culturally and geographically similar i.e., bordering countries. The next two dummies capture the effects of firm-specific industrial and size heterogeneities in response to the institutional difference between

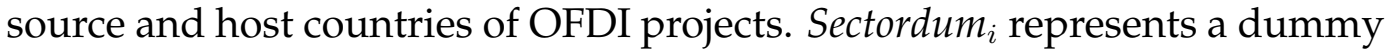
variable that equals one if the investor $i$ (parent organization/headquarters) belongs to the manufacturing sector in its home country and zero otherwise. Similarly, Sizedum $i$ represents a dummy variable that equals one if the number of employees of investor $i$ is above 250 (large multinational organization) and zero otherwise (medium to small multinational organization) ${ }^{19}$

\footnotetext{
${ }^{19}$ Due to data limitations and a small sample size it was not possible to add detailed firmspecific industrial and ownership information in the analysis. Therefore, the sample was divided into manufacturing and service industry affiliates using first 2 digits of NACE codes, whereas the classification of firm size is based on the European Commission's definition of organization size classes in terms of number of employees i.e., organization is considered large if no. of employees $>250$, organization is considered medium/smallsized if no. of employees $<250$.
} 
Tables 3 presents the descriptive and Table 3A (in the Annex) presents the collinearity statistics, respectively. The Variance Inflation Factor (VIF) was computed before and after the regressions; the mean VIF (2.92) was well below the acceptable threshold of 10 (Neter et al., 1985), and the tolerance level for each variable was more than 0.1 . These values indicate that the estimation data did not suffer from serious problems of multicollinearity. However, the variable of host country wages (an appropriate variable to approximate efficiency-seeking behavior) had to be excluded from the specifications due to high correlation and no suitable instrument could be identified.

Table 3 - Descriptive Statistics of Variables

\begin{tabular}{lccc}
\hline Variables & Observations & Mean & Std. Deviation \\
\hline PP & 24726 & 71.9494 & 18.3277 \\
CF & 24726 & 62.6414 & 21.71226 \\
FF & 24726 & 57.201 & 14.69697 \\
BF & 24726 & 75.1191 & 9.964759 \\
FiF & 24726 & 67.2725 & 15.9083 \\
MF & 24726 & 78.4012 & 13.65912 \\
MKTSIZE & 24726 & 9.49296 & 0.9190593 \\
MKTGROWTH & 24726 & 3.6408 & 2.850488 \\
R\&D & 24726 & 1.35305 & 0.897347 \\
HRSTO & 24726 & 7.16406 & 1.474153 \\
PDENS & 24726 & 172.442 & 233.0282 \\
INF & 24726 & 52.2837 & 26.74736 \\
PROXIMITY & 24726 & 6.85167 & 0.6471716 \\
\hline \hline
\end{tabular}

Source: Own calculations

\section{Estimation Results}

The estimation sample consists of the OFDI location choices of 951 CEEC investors (between the years 1995 and 2010) after adjusting for missing observations and inconsistencies in the data. As previously discussed, the signs and the coefficients of the main explanatory variables show the importance of the host country's economic institutions for the OFDI location choice. Several models were tested to check the robustness of the regression models and the relative importance of key hypotheses of this study.

\subsection{Main Results}

Table 4 displays the results of the regression model stipulated in specification (1) for the likelihood of location choices of CEEC investors. Column (1) presents the conditional logit model estimation results for the full sample (EU27) by estimating the location likelihood of investors from each source 
country to each host country. The remaining columns of Table 4 represent the geographical subsets of the sample. Column (2) displays the estimation results of the location likelihood of 399 CEEC investors in the fifteen advanced economies of the EU (EU15), whereas column (3) shows the results for the location likelihood of 552 investors in ten emerging economies of the EU (CEECs). The underlying intention in such geographical differentiation is to detach the differences among investors analogous to the attributes of the host countries (advanced economies and the emerging economies of the EU) to account for unobserved country-specific heterogeneity ${ }^{20}$ The test statistics of all estimations were significantly different from zero, which allows for the interpretation of the coefficients.

Table 4 shows that features of property rights protection (PP) in host countries did not influence the location choices by CEEC investors (see column 1 of Table 4). However, the null hypothesis can be rejected because property rights protection was a positive and significant determinant (at the $5 \%$ level) of location choices in the advanced economies of the EU (see column 2 of Table 4). This result lends some support to hypothesis (1) and is consistent with the current scholarship on the importance of contract enforcements and property rights in foreign locations (e.g., Kostava and Zaheer, 1999). Nonetheless, this result was insignificant for location choices in other CEECs (see column 3 of Table 4). These results suggest that CEEC investors would prefer countries with better protection of property rights while investing in the advanced economies of the EU, rather than in CEECs. These results can be linked to the intense economic competition and high risk of exit from the markets in the EU15. Given the argument that emerging-economy multinational organizations are limited in resources and competitively disadvantaged, CEEC investors may be inclined to seek protection against potential market exit when there is challenging economic competition in advanced economies.

Freedom from corruption (CF) had an economically and statistically significant (at the $0.01 \%$ level) influence on the OFDI location likelihood in the EU, confirming hypothesis (2). The influence was also significant (at the $5 \%$ level) on the investments made in the EU15. However, the effect of freedom from corruption was insignificant for investors located in other CEECs. These results demonstrate that, although a lower level of corruption in host countries had a strong influence on the likelihood of location choices of CEEC investors, this influence generally varied with the host country group. CEEC investors did not consider the levels of corruption in other CEECs to be an important investment concern, which may reinforce the view that foreign investors may resort to corruption practices to accelerate business operations and transactions in host countries that have inefficient bureaucracies (Bardhan, 1997), which is the typical case of most post-communist countries that are saturated with significant levels of cor-

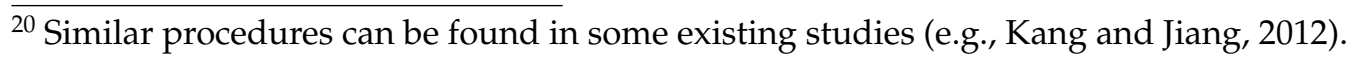


Table 4 - CLM Estimation Results of the Specification (1)

\begin{tabular}{lccc}
\hline \hline & EU27 & EU15 & CEECS \\
& $(1)$ & $(2)$ & $(3)$ \\
\hline PP & -0.000778 & $0.0352^{*}$ & 0.00564 \\
& $(0.00497)$ & $(0.0173)$ & $(0.00851)$ \\
CF & $0.0351^{* * *}$ & $0.0265^{*}$ & -0.0105 \\
& $(0.00488)$ & $(0.0132)$ & $(0.00810)$ \\
FF & $0.0415^{* * *}$ & $0.0405^{* * *}$ & -0.00708 \\
& $(0.00451)$ & $(0.01000)$ & $(0.00954)$ \\
BF & $0.0474^{* * *}$ & 0.00225 & $0.0592^{* * *}$ \\
& $(0.00525)$ & $(0.0125)$ & $(0.00974)$ \\
FiF & $0.0115^{* * *}$ & $0.0211^{*}$ & 0.0110 \\
& $(0.00311)$ & $(0.00915)$ & $(0.00585)$ \\
MF & 0.00654 & 0.0253 & $0.0159^{* *}$ \\
& $(0.00481)$ & $(0.0347)$ & $(0.00595)$ \\
MKTSIZE & $-1.045^{* * *}$ & 1.023 & $-2.658^{* * *}$ \\
& $(0.129)$ & $(0.675)$ & $(0.390)$ \\
MKTGROWTH & 0.0308 & -0.0443 & $0.0877^{* * *}$ \\
& $(0.0174)$ & $(0.0671)$ & $(0.0250)$ \\
R\&D & $-0.622^{* * *}$ & $-0.670^{* *}$ & $2.027^{* * *}$ \\
& $(0.122)$ & $(0.241)$ & $(0.374)$ \\
HRSTO & $0.712^{* * *}$ & $1.096^{* * *}$ & $0.605^{* *}$ \\
PDENS & $(0.0491)$ & $(0.177)$ & $(0.212)$ \\
& $0.00235^{* * *}$ & -0.000445 & -0.00584 \\
INF & $(0.000358)$ & $(0.00123)$ & $(0.00516)$ \\
& $-0.0112^{* * *}$ & -0.00569 & -0.00232 \\
PROXIMITY & $(0.00316)$ & $(0.00954)$ & $(0.00672)$ \\
& $-1.582^{* * *}$ & $-0.693^{* * *}$ & $-2.640^{* * *}$ \\
Firms & $(0.0601)$ & $(0.163)$ & $(0.133)$ \\
Obs. & 951 & 399 & 552 \\
BIC & 24726 & 5985 & 6072 \\
Cog lik. & 4460.1 & 1303.0 & 1496.7 \\
\hline & 4565.6 & 1390.0 & 1583.9 \\
& -2217.1 & -638.5 & -735.3 \\
& 1184.9 & 586.3 & 551.3 \\
\hline & & & \\
& & & \\
& & &
\end{tabular}

Standard errors in parentheses, ${ }^{*} p<0.05,{ }^{* *} p<0.01,{ }^{* * *} p<0.001$ 
ruption (Sandholtz and Taagepera, 2005).

With respect to the influence of host country taxation, fiscal freedom (FF) in the host country had a positive and significant (at the $0.1 \%$ level) effect on the location choices by CEEC investors in the EU. This result supports hypothesis (3) that a country's low tax burden increases the likelihood of choosing that country by CEEC investors. Although the coefficient of the variable remained significant (at the $0.1 \%$ level) for the investments made in the EU15, it was insignificant for location choices in CEECs, which goes against some existing evidence (e.g., Bellak and Leibrecht, 2009). A possible explanation for this contradiction might be the difference between the prevailing tax regimes in the EU15 and CEECs. Taxes, and corporate taxes in particular, are generally lower in most CEECs; thus, the tax burdens imposed on foreign investors in CEECs are comparatively lower than in the EU15.

The coefficients of business regulatory variables, i.e., business freedom (BF) and financial freedom (FiF), were also economically and statistically significant (at the $0.1 \%$ level) in the full sample estimation which confirms hypothesis (4) and supports other empirical evidence on the subject (e.g., Botero et al., 2004; Djankov et al., 2002). However, the influence of business freedom was insignificant for location choices in the EU15, whereas positive and significant (at the $0.1 \%$ level) for entries in CEECs. Similarly, the influence of host country financial freedom differed across the EU15 and CEECs. Financial freedom in the host country had a positive and significant (at the 5\% level) influence on the location choices in the EU15, and an insignificant influence on the location choices in CEECs. These results suggest that the CEEC investors were facilitated by business friendliness of similar economies and the prospects of local financing in the advanced economies of the EU. It should be noted that the business freedom is generally supported through comparatively efficient business friendliness and long-standing privatizations in the EU15. By contrast, in the CEECs, the risk of starting and maintaining a business may be higher due to inefficient bureaucracies and the institutional remnants of communist regimes. Therefore, the intrinsic attributes of CEEC institutions can make investors cautious of failed outcomes in similar settings, which may explain the importance of business freedom in these countries for CEEC investors. Moreover, the advanced economies of the EU15 are traditionally home to significant levels of inward investments, and it may be difficult to secure local capital for business operations in the presence of a large number of foreign investors. Consequently, it may also be challenging for CEEC investors to secure local financing in the host countries of the EU15, thus making it an important concern for location choices by CEEC investors in the advanced economies.

Surprisingly, monetary freedom (MF) was an insignificant indicator for the entire sample estimation and for investments in the EU15. However, 
monetary freedom significantly (at the 1\% level) affected the likelihood of investment by CEEC investors in other CEECs. Thus, we cannot reject hypothesis (5). A possible interpretation of this result might be found in the different price control mechanisms in the advanced and the emerging economies of the EU. CEECs are considered to feature excessive monetary supplies and inefficient price controls. Therefore, CEEC investors may be more sensitive to inflation levels to avoid additional costs of investments and profit reduction in similar economies, which confirms the findings of other researchers (e.g., Clausing and Dorobantu, 2005). Moreover, CEEC investors may have experienced the adverse effects of poor monetary mechanisms in their home countries, thus making them warily conscious of the effects of macroeconomic instability in the host country.

Regarding the control variables employed in the estimations, the results in Table 4 reveal a significantly negative effect of the host country's market size (MKTSIZE) on the likelihood of establishing OFDI in the whole sample estimation and in the subgroup of CEECs (see column 1 and 3 of Table 4 , respectively). The coefficient was insignificant for the location choices in the advanced economies (see column 2 of Table 4). These results imply that the market differences in the sets of host countries do not possibly explain the OFDI location dynamics defined by the host market sizes in the EU15 and CEECs. However, market growth (MKTGROWTH) positively influenced the likelihood of investments in the CEECs, i.e. CEEC investors were more likely to locate their affiliates in the emerging economies of the EU that were characterized by higher economic growth during the observation period. This result therefore partly supports the existing international business theory that states that OFDI is attracted by the market prospects of host economies. Furthermore, a negative coefficient of the host country's research endowments (R\&D) was observed in the whole sample estimation and in the EU15 subset, whereas a positive influence was observed in the CEECs subset. However, the availability of the skilled labor (HRSTO) inferred a positive effect on the location probability of CEEC investors in the whole sample and in the subsets. The implication arising from these results suggests that the knowledge-related aspects of host countries matter, to some extent, for the location of foreign affiliates by the investors from CEECs. The corresponding implication agrees with the literature that host country's knowledge-related factors may increase the propensities of EMBGs to locate their affiliates in the host country ${ }^{21}$

With regard to other control variables, Table 4 reports that the coefficients of the population density (PDENS) and communication infrastruc-

\footnotetext{
${ }^{21}$ The view underscores that EMBGs may look for knowledge resources that can be internalized within groups to successively attain updated capabilities essential to compete elsewhere. The argument is related to the EMBGs' intrinsic ownership weaknesses inter alia their technological constraints and their latent entries in the global business when compared to their counterparts in the advanced economies (Mathews, 2006; Luo and Tung, 2007; Mathews and Zander, 2007; Li, 2007).
} 
ture (INF) were statistically and positively significant for the whole sample whereas they were insignificant for both the subsets of EU15 and CEECs (see column 1, 2 and 3 of Table 4, respectively).These results suggest that the differences in the urbanization and communication infrastructure do not explain the extent of OFDI location choices of CEEC investors when the country of destination heterogeneity is taken into account. Moreover, the coefficients of proximity (PROXIMITY) in all three models were negative and statistically significant. These results are in line with the existing theory, which states that OFDI is negatively related to the geographical distance between the home country of investor and the host country.

\subsection{Results on the Effects of Institutional Differences}

Table 5 shows the conditional logit estimation results corresponding to the regression specifications (2) and (3). The results are obtained by estimating the effects of the relative differences between the main explanatory variables (property rights protection, freedom from corruption, fiscal freedom, business freedom, financial freedom and monetary freedom) of the source country and the host country on the location choices of CEEC investors. ${ }^{22}$

It was assumed in the baseline model (column 4 of Table 5) that the differences in economic institutions affect the utility function of CEEC investors uniformly for the likelihood of establishing their affiliates in the EU. The estimation results of specification (2) reveal that, apart from property rights protection and monetary freedom in host countries, the OFDI location likelihood was positively influenced by the differences between the institutional quality of the source countries and the host countries (see column 4 of Table 5). It is notable that the coefficients of the freedom from corruption, fiscal freedom, business freedom and financial freedom are significantly larger (compared to the results of column 1 of Table 4), which implies that CEEC investors would prefer to locate their affiliates in countries with comparatively less corruption, lower tax burdens, more favorable business environments and better prospects of securing local financing than in their home countries.

Estimations presented in columns 5-7 of Table 5 relaxed the main assumption of the baseline model i.e., specification (2) (column 4 of Table 5) by introducing the interaction effects of unobserved effects stipulated in specification (3). In doing so, it was possible to examine how common border and firm heterogeneities among investors would respond to the institutional differences argument.

The results in column (5) reveal that the effects of freedom from corruption and financial freedom were significantly small on the likelihood of

\footnotetext{
$\overline{22}$ Because the study utilizes ranking-based indices (see Table 2) to measure the effects of the institutional quality, it was possible to compute relative differences between the economic institution of source and destination countries.
} 
Table 5 - CLM Estimation Results of Specifications (2) and (3)

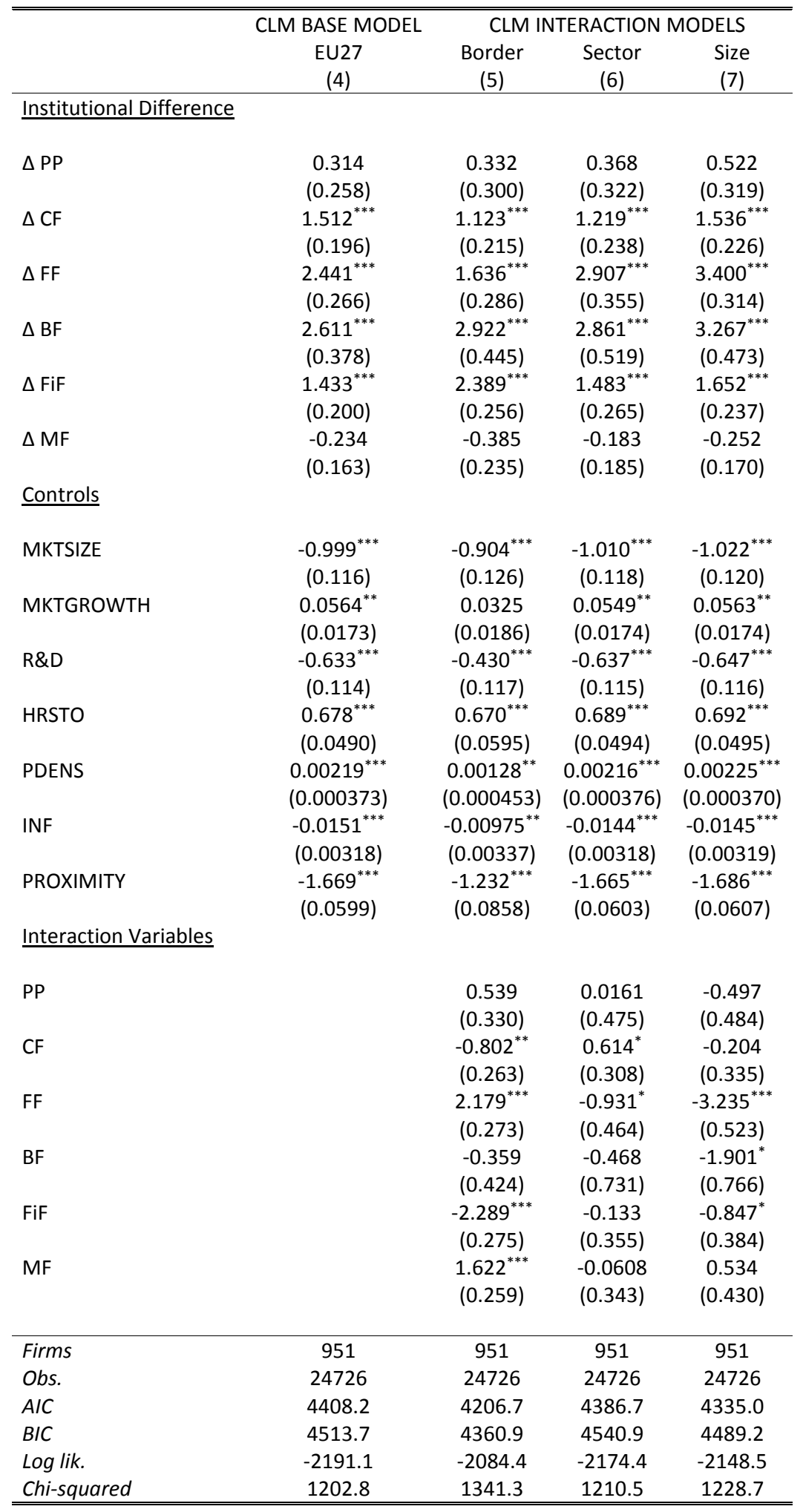

Standard errors in parentheses, ${ }^{*} p<0.05,{ }^{* *} p<0.01,{ }^{* * *} p<0.001$ 
establishing affiliates in bordering countries compared to the control group, whereas the effects of fiscal freedom and monetary freedom were significantly larger on the location likelihood of CEEC investors. These results suggest the following: First, CEEC investors tended to prefer bordering countries with relatively low tax burdens and stable economies compared to their host countries. Second, the comparative levels of corruption and regulations concerning local financing were not of significant value for CEEC investors in bordering countries. The first observation is consistent with the conventional theory in which firms initially expand to neighboring countries after gaining experience in the domestic market and look for the prospects of higher profits in similar but new environments (Johanson and Vahlne, 1977, 2009). Furthermore, it would be more beneficial for CEEC investors if investments were made in neighboring countries in which the tax burdens and higher inflation rates do not affect profitability. With regard to the second observation, CEEC investors preferred to operate in the similar business environments of bordering countries based on common historical and political ties among CEECs, where countries were either under a common regime type (socialist economy) or consisted of one country (e.g., Yugoslavia). Likewise, the CEEC investors would be more familiar with the similar bureaucratic inefficiencies in business operations and with local capital allocations, thus making them less sensitive to the differences between home and host countries in the levels of corruption and financial regulations.

The results concerning the industrial heterogeneity of investors (investors from manufacturing sector against the control group of service sector) are reported in column 6 of Table 5. The results demonstrate that investors from the manufacturing industry preferred countries with higher freedom from corruption than their respective countries. However, the effect of differences in the fiscal freedoms of home and host countries on the location choices was positive but smaller than those on the control group. These results suggest that investors from the manufacturing industry were, by and large, less affected by institutional differences than investors from the service industry. Investors in the manufacturing sector were nevertheless comparatively more sensitive to corruption in host countries, in which supply inputs are impeded by corrupt systems. Moreover, these investors were also likely (although less likely than investors in the service sector) to invest in countries providing more fiscal freedoms than their home countries, which corresponds to higher profitability after taxation.

Finally, column (7) presents the estimation results by interacting the observed variables with the size of the investors (i.e., large EMBGs against the control group of medium/small EMBGs). The coefficients suggest that the location choices of larger EMBGs were generally less affected by the country differences pertaining to fiscal freedom, business freedom, and financial freedom than the control group was. These results support the argument 
that large firms are better off in counterpoising the costs and risks of foreign entry due to their better resources and access to capital in their home countries (Lall, 1986).

\section{Conclusions}

The significant rise in multinational organizations from emerging economies has inspired a substantial body of knowledge that has examined the development, evolution and internationalization motives of EMBGs in homecountry institutional settings (Yaprak and Karademir, 2010). However, there has been little debate on how host-country institutions influence the foreign location strategies of EMBGs. Therefore, this study sought to contribute to the existing knowledge on the relationship between the host-country institutional environment and OFDI location choices of EMBGs, particularly those in the EU.

This study argued that in addition to conventional OFDI location factors, the economic institutional environments of host countries are also important for EMBGs because of the weak ownership capabilities of these investors, as suggested by prominent researchers (Hoskisson et al., 2000, Ramamurti, 2009. 2012; Li, 2007). Therefore, these firms are more likely to be affected by the investment uncertainties, foreign entry risks and high operating costs in target countries. Moreover, this study noted that while it is important to analyze the effect of economic institutions on OFDI location activities in emerging economies, it is equally important to examine the influence of economic institutions on the location activities of EMBGs in advanced economies.

Therefore, this study empirically examined the influence of different economic institutions on the firm-level OFDI location choices of EMBGs from CEECs. The theoretical foundation of this study was a relatively new component of the extant literature, namely new institutional economics. In this way, this study focused on the role of economic institutions in the OFDI location decisions of 951 CEEC investors from 1995 to 2010. Along with the conventional determinants of OFDI, six institutional indices were used to measure how the institutional environment of a host country affects the location choices of foreign affiliates owned by CEEC investors in the EU. The estimation results were then obtained by using the widely used discrete choice maximum likelihood method (McFadden, 1974).

Apart from the complexities in measuring institutional quality, this study was able to interpret some interesting findings. The robust empirical evidence suggests that a corruption-free country with a low tax burden and favorable business regulations positively influences the OFDI location choices of CEEC investors. However, these factors vary depending on the economic location of the country that receives the investment (i.e., advanced or emerging economy). In particular, the effects of economic institutions are stronger 
on location choice activities in the advanced countries of the EU than on those in other CEECs.

This study also examined how institutional differences such as the institutional distance of the investing country from the OFDI destination country affect the location decisions of EMBGs in the EU. The results demonstrated that CEEC investors generally prefer to be located in countries that have more stable institutions than those in their home countries. Furthermore, the empirical evidence provided in the study supports the argument that these investors are likely to locate their affiliates in similar markets because of cultural and geographical proximities. Moreover, the study explicitly acknowledged the prevailing heterogeneity among investors as demonstrated in the empirical results relating to their size diversity and industrial orientation.

The empirical evidence presented in this study indicates some possible implications for the foreign entry debate of EMBGs. First, in addition to conventional OFDI location determinants, the institutional factors of the host country play an important role in the location decisions of EMBGs. Moreover, with regard to European EMBGs, this role is not only limited to the location strategies adopted for investing in other emerging economies but is also more evident when choosing OFDI locations in the advanced economies of the EU.

Second, the empirical findings of this study confirm that the institutional differences between home and host countries play a major role in OFDI activities (Bénassy-Quéré et al., 2007). Finally, the theoretical construct and empirical results of the study indicate the usefulness of the incrementalization of the OLI model with the concepts that scholars have deemed to be applicable to the internationalization of EMBGs with regard to their distinctive functionalities (e.g., Yaprak and Karademir, 2010).

In more general terms, the analysis presented in this paper also suggests certain potential implications for the literature that analyzes the formation and transformation of EMBGs in the institutional context. For instance, according to the institutional voids thesis, business groups are typically expected to perform relatively well in countries where institutions are inefficient and not well functioning (Khanna and Yafeh, 2007). However, this study showed that EMBGs, when they internationalize their activities through OFDI, prefer to locate in economic environments characterized by well-functioning market institutions. This finding may lead to the question of why business groups thrive in inefficient domestic environments but choose efficient markets when locating abroad. The relationship between the standard predictions of the institutional voids thesis and location choice of business groups' OFDI is thus an interesting avenue for future research.

This study also suffers from some methodological issues that should be addressed in future research. The firm-level data used in this study are restricted to the location decisions of CEEC investors. To find more informa- 
tion about the relevance of economic institutions on the OFDI location activities of EMBGs, future researchers should examine the relocation strategies of EMBGs from other emerging economies as well as their performances in diverse foreign locations that operate under different institutional regimes. This approach could isolate the similarities and differences between different EMBGs on the grounds of home-country institutional development and their subsequent patterns (Hoskisson et al., 2000). Future research should also aim to address the shortcomings with regard to the accurate measurement of the variables used in this analysis. This limitation could be overcome by using proxies of economic institutions at a more disaggregated level of explanatory power to capture the effects of unobserved institutional factors, especially informal institutions. 


\section{References}

Agarwal, J., 1980. Determinants of Foreign Direct Investment: A Survey. Weltwirtschaftliches Archiv 116, 739-773. doi:10.1007/BF02696547

Altomonte, C., Rungi, A., 2013. Business Groups as Hierarchies of Firms: Determinants of Vertical Integration and Performance. Paolo Baffi Centre Research Paper Series No. 2013-135. Bocconi University. doi:10.2139/ssrn.2239598

Asiedu, E., 2006. Foreign Direct Investment in Africa: The Role of Natural Resources, Market Size, Government Policy, Institutions and Political Instability. World Economy 29, 63-77. doi:10.1111/j.1467-9701.2006.00758.x

Bardhan, P., 1997. The Role of Governance in Economic Development: A Political Economy Approach. OECD Development Centre, Paris.

Barro, R., 1996. Democracy and Growth. Journal of Economic Growth 1, 127. doi:10.1007/BF00163340

Basile, R., Castellani, D., Zanfei, A., 2008. Location Choice of Multinational Firms in Europe: The Role of EU Cohesion Policy. Journal of International Economics 74, 328-340. doi:10.1016/j.jinteco.2007.08.006

Bellak, C., Leibrecht M., 2009. Do low Corporate Income Tax Rates attract FDI? Evidence from Central- and East European Countries. Applied Economics 41, 2009. doi:10.1080/00036840701320217

Bénassy-Quéré, A., Coupet, M., Mayer, T., 2007. Institutional Determinants of Foreign Direct Investment. The World Economy 30, 764-782. doi:10.1111/j.1467-9701.2007.01022.x

Beugelsdijk, S., Hennart, J., Slangen, A., Smeets, R., 2010. Why and how FDI stocks are a biased measure of MNE affiliate activity. Journal of International Business Studies 41, 1444-1459. doi:10.1057/jibs.2010.29

Bevan, A., Estrin, S. The Determinants of Foreign Direct Investment into European Transition Economies, Journal of Comparative Economics 32, 775787. doi:10.1016/j.jce.2004.08.006

Bevan, A., Estrin, S., Meyer, K., 2004. Foreign Investment Location and Institutional Development in Transition Economies. International Business Review 13, 43-64. doi:10.1016/j.ibusrev.2003.05.005

Biswas, R., 2002. Determinants of Foreign Direct Investment. Review of Development Economics 6, 492-504. doi:10.1111/1467-9361.00169 
Blonigen, B., 2005. A Review of the Empirical Literature of FDI Determinants. Atlantic Economic Journal 33, 383-403. doi:10.1007/s11293-0052868-9

Botero, J., Djankov, S., La Porta, R., Lopez-de-Silanes, F., Shleifer, A., 2004. The Regulation of Labor. Quarterly Journal of Economics 119, 1339-1382. doi:10.1162/0033553042476215

Botrić, V., Škuflić, L., 2006. Main Determinants of Foreign Direct Investment in the Southeast European Countries. Transition Studies Review 13, 359377. doi:10.1007/s11300-006-0110-3

Brainard, S., 1997. An Empirical Assessment of the Proximity- Concentration Trade-off between Multinational Sales and Trade. American Economic Review 87, 520-544.

Brenton, P., Di Mauro, F., Lücke, M., 1999. Economic Integration and FDI: An Empirical Analysis of Foreign Investment in the EU and in Central and Eastern Europe. Empirica 26, 95-121. doi:10.1023/A:1007006429600

Buckley, P., Hashai, N., 2008. Formalizing Internationalisation in the Eclectic Paradigm. Journal of International Business Studies 40, 1-13.

Buckley, P., Clegg, J., Cross A., Liu, X., Voss, H., Zheng, P., 2007. The Determinants of Chinese Outward FDI. Journal of International Business Studies 38, 499-518. doi:10.1057/palgrave.jibs.8400277

Cassou, S., 1997. The Link between Tax Rates and Foreign Direct Investment. Applied Economics 29, 1295-1301. doi:10.1080/00036849700000019

Castellacci, F., 2013. Institutional Voids or Entry Barriers? Business Groups, Innovation and Market Development in Emerging Economies. Science and Technology Policy Research Unit Working Paper Series No. 2013-05.

Chacar, A., Newberry, W., Vissa, B., 2010. Bringing Institutions into Performance Persistence Research: Exploring the Impact of Product, Financial, and Labor Market Institutions. Journal of International Business Studies 41, 1119-1140. doi:10.1057/jibs.2010.3

Child, J., Rodrigues, S., 2005. The Internationalization of Chinese Firms: A Case for Theoretical Extension?. Management and Organization Review 1, 381-410. doi:10.1111/j.1740-8784.2005.0020a.x

Clausing, K., Dorobantu, C., 2005. Re-entering Europe: Does European Union Candidacy Boost Foreign Direct Investment?. The Economics of Transition 13, 77-103. doi:10.1111/j.1468-0351.2005.00208.x 
Cleeve, E., 2008. How Effective are Fiscal Incentives to Attract FDI to Sub-Saharan Africa?. The Journal of Developing Areas 42, 135-153. doi:10.1353/jda.0.0015

Cotton, L., Ramachandran, V., 2001. Foreign Direct Investment in Emerging Economies: Lessons from Sub-Saharan Africa. World Institute for Development Economics Research, Discussion Paper No. 2001/82.

Coughlin, C., Joseph, V., Arromdee, V., 1991. State Characteristics and the Location of Foreign Direct Investment within the United States. Review of Economics and Statistics 73, 675-83. doi:10.2307/2109406

Daude, C., Stein, E., 2007. The Quality of Institutions and Foreign Direct Investment. Economics \& Politics 19, 317-344. doi:10.1111/j.14680343.2007.00318.x

Devereux, M., Griffith, R., 1998. Taxes and Location of Production: Evidence from a Panel of US Multinationals. Journal of Public Economics 68, 335-367. doi:10.1016/S0047-2727(98)00014-0

Disdier, A., Mayer, T., 2004. How Different is Eastern Europe? Structure and Determinants of Location Choices by French Firms in Eastern and Western Europe. Journal of Comparative Economics 32, 280-296. doi:10.1016/j.jce.2004.02.004

Djankov, S., La Porta, R., Lopez-de-Silanes, F., Shleifer, A., 2002. The Regulation of Entry. Quarterly Journal of Economics 117, 1-37. doi:10.1162/003355302753399436

Dunning, J., 1977. Trade, Location of Economic Activity and the MNE: A Search for an Eclectic Approach. In: Ohlin, B., Hesselborn, P.O., Wijkman, P.M. (Eds.), The International Allocation of Economic Activity. Macmillan, London and Basingstoke, pp. 395-418.

Dunning, J., 1979. Explaining Changing Patterns of International Production: A Search for the Eclectic Theory. Oxford Bulletin of Economics and Statistics 161, 269-295.

Dunning, J., 1988. The Eclectic Paradigm of International Production: A Restatement and Some Possible Extensions. Journal of International Business Studies 19, 1-31. doi:10.1057/palgrave.jibs.8490372

Dunning, J., 1993. Commentary: How Should National Governments Respond to Globalization?. The International Executive 35, 187-198. doi:10.1002/tie.5060350302

Dunning, J., Lundan, S., 2008. Multinational Enterprises and the Global Economy. Edward Elgar Publishing Limited, Cheltenham. 
Dunning, J., 2010. New Challenges for International Business Research. Edward Elgar Publishing Limited, Cheltenham. doi:10.4337/9781849808064

Estrin, S., Hughes, K., Todd, S., 1997. Foreign Direct Investment in Central and Eastern Europe: Multinationals in Transition. Royal Institute of International Affairs Printer, London and Washington.

Faeth, I., 2009. Determinants of Foreign Direct Investment-A Tale of Nine Theoretical Models. Journal of Economic Surveys 23, 165-196. doi:10.1111/j.1467-6419.2008.00560.x

Gammeltoft, P., 2008. Emerging Multinationals: Outward FDI from the BRICS Countries. International Journal of Technology and Globalisation 4, 5-22. doi:10.1504/IJTG.2008.016184

Gorter, J., and Parikh, A., 2003. How Sensitive is FDI to Differences in Corporate Income Taxation within the EU. De Economist 151, 193-204. doi:10.1023/A:1023913618978

Griffin, R., Pustay, M., 2009. International Business: A Managerial Perspective, Pearson Prentice Hall-Pearson Education International, New Jersey.

Grosse, R., Trevino, L., 2005. New Institutional Economics and FDI Location in Central and Eastern Europe. Management International Review 45, 123145 .

Guillén, M., 2000. Business Groups in Emerging Economies: A Resource-Based View. Academy of Management Journal 43, 362-80. doi:10.2307/1556400

Guiso, L., Sapienza, P., Zingales, L., 2009. Cultural Biases in Economic Exchange? Quarterly Journal of Economics 124, 1095-1131. doi:10.1162/qjec.2009.124.3.1095

Guimarães, P., Figueiredo, O., Woodward, D., 2004. Industrial Location Modelling: Extending the Random Utility Framework. Journal of Regional Science 44, 1-20. doi:10.1111/j.1085-9489.2004.00325.x

Habib, M., Zurawicki, L., 2001. Country-Level Investments and the Effect of Corruption - Some Empirical Evidence. International Business Journal 10, 687-700.

Harriss, J., Hunter, J., Lewis, C., 1995. The New Institutional Economics and Third World Development. Routledge, London.

Helpman, E., 1984. A Simple Theory of International Trade with Multinational Corporations. Journal of Political Economy 92, 451-471. doi:10.1086/261236 
Helpman, E., Melitz, M., Rubinstein, Y., 2008. Estimating Trade Flows: Trading Partners and Trade Volumes. The Quarterly Journal of Economics 123, 441-487. doi:10.1162/qjec.2008.123.2.441

Henisz, W., 2003. The Power of the Buckley and Casson Thesis: The Ability to Manage Institutional Idiosyncrasies. Journal of International Business Studies 34, 173-184.

Hines, J., 1995. Taxes, Technology Transfer, and the R\&D Activity of Multinational Firms. In: Feldstein, M., Hines, J. Jr., and Hubbard, R.G. (Eds.), The Effects of Taxation on Multinational Corporations, University of Chicago Press, Chicago, pp. 225-48.

Hoskisson, R., Eden, L., Lau, C., Wright, M., 2000. Strategy in Emerging Economies. Academy of Management Journal 43, 249-267. doi:10.2307/1556394

Jain, A., 2001. Corruption: A Review. Journal of Economic Surveys 15, 71121. doi:10.1111/1467-6419.00133

Jaklič, A., Svetličič, M., 2003. Enhanced Transition through Outward Internationalization: Outward FDI by Slovenian Firms. Ashgate, Burlington.

Johanson, J., Vahlne, J., 1977. The International Process of the Firm. A Model of Knowledge Development and Increasing Foreign Market Commitments. Journal of International Business Studies 8, 23-32. doi:10.1057/palgrave.jibs.8490676

Johanson, J., Vahlne, J., 2009. The Uppsala Internationalization Process Model Revisited: From Liability of Foreignness to Liability of Outsidership. Journal of International Business Studies 40, 1411-1431. doi:10.1057/jibs.2009.24

Kang, Y., Jiang, F., 2012. FDI Location Choice of Chinese Multinationals in East and Southeast Asia: Traditional Economic Factors and Institutional Perspective. Journal of World Business 47, 45-53. doi:10.1016/j.jwb.2010.10.019

Keister, L., 1998. Engineering Growth: Business Group Structure and Firm Performance in China's Transition Economy. American Journal of Sociology 104, 404-440. doi:10.1086/210043

Khanna, T., Palepu, K., 1997. Why Focused Strategies may be Wrong for Emerging Markets?. Harvard Business Review 75, 41-51.

Khanna, T., Palepu, K., 2000. The Future of Business Groups in Emerging Markets: Long-Run Evidence from Chile. Academy of Management Journal 43, 268-285. doi:10.2307/1556395 
Khanna, T., Yafeh, Y., 2007. Business Groups in Emerging Markets: Paragons or Parasites?. Journal of Economic Literature 45, 331-372. doi:10.1257/jel.45.2.331

Kinda, T, 2010. Investment Climate and FDI in Developing Countries: Firm-Level Evidence. World Development 38, 498-513. doi:10.1016/j.worlddev.2009.12.001

Kobeissi, N., 2005. Impact of Governance, Legal System and Economic Freedom on Foreign Investment in the MENA Region. Journal of Comparative International Management 8, 20-41.

Kock, C., Guillén, M., 2001. Strategy and Structure in Developing Countries: Business Groups as an Evolutionary Response to Opportunities for Unrelated Diversification. Industrial and Corporate Change 10, 77-113. doi:10.1093/icc/10.1.77

Kostava, T., Zaheer, S., 1999. Organizational Legitimacy under Complexity. Academy of Management Review 24, 64-81.

Kostova, T., 1996. Success of the Transnational Transfer of Organizational Practices within Multinational Companies. University of Minnesota Press, Minneapolis.

La Porta, R., Lopez-de-Silanes, F., Shleifer, A., Vishny, R., 1997. Legal Determinants of External Finance. Journal of Finance 52, 1131-1150. doi:10.1111/j.1540-6261.1997.tb02727.x

Lall, R., 1986. Third World Multinationals: The Characteristics of Indian Firms Investing Abroad. Journal of Development Economics 20, 381-397. doi:10.1016/0304-3878(86)90031-3

Lankes, H., Venables, A., 1996. Foreign Direct Investment in Economic Transition: The Changing Pattern of Investments. Economics of Transition 4, 331- 347. doi:10.1111/j.1468-0351.1996.tb00176.x

Levchenko, A., 2003. Institutional Quality and International Trade. MIT Press, Cambridge.

Li, P., 2007. Toward an Integrated Theory of Multinational Evolution: The Evidence of Chinese Multinational Enterprises as Latecomers. Journal of International Management 13, 296-318. doi:10.1016/j.intman.2007.05.004

Lim, E-G., 2001. Determinants of, and the Relation Between, Foreign Direct Investment and Growth: A Summary of the Recent Literature. IMF Working Paper No. 01/175. 
Luo, Y., Tung, R., 2007. International Expansion of Emerging Market Enterprises: A Springboard Perspective. Journal of International Business Studies 38, 481-498. doi:10.1057/palgrave.jibs.8400275

Markusen, J., Maskus, K., 2002. Discriminating among Alternative Theories of the Multinational Enterprise. Review of International Economics 10, 694707. doi:10.1111/1467-9396.00359

Markusen, J., Venables, A., 2007. Interacting Factor Endowments and Trade Costs: A Multi-country, Multi-good Approach to Trade Theory. Journal of International Economics 73, 333-354. doi:10.1016/j.jinteco.2007.03.005

Mathews, J., 2002. Competitive Advantages of the Latecomer Firm: A Resource-Based Account of Industrial Catch-Up Strategies. Asia Pacific Journal of Management 19, 467-488. doi:10.1023/A:1020586223665

Mathews, J., 2006. Dragon Multinationals: New Players in 21st Century Globalization. Asia Pacific Journal of Management 23, 5-27. doi:10.1007/s10490-006-6113-0

Mathews, J., Zander, I., 2007. The International Entrepreneurial Dynamics of Accelerated Internationalization. Journal of International Business Studies 38, 387-403. doi:10.1057/palgrave.jibs.8400271

McFadden, D., 1974. Conditional Logit Analysis of Qualitative Behaviour. In: P. Zarembka (Ed.), Frontiers in Econometrics. Academic Press, New York, pp.105-142.

Meyer, K., 1998. Direct Investment in Economies in Transition. Edward Elgar, Aldershot and Northampton.

Meyer, K., 2001. Institutions, Transaction Costs and Entry Mode Choice in Eastern Europe. Journal of International Business Studie, 32, 357-367. doi:10.1057/palgrave.jibs.8490957

de Mooij, R., Ederveen, S., 2001. Taxation and Foreign Direct Investment: A Synthesis of Empirical Research. International Tax and Public Finance 10, 673-693. doi:10.1023/A:1026329920854

Mudambi, R., Navarra, R., 2002. Institutions and International Business: A Theoretical Overview. International Business Review 11, 635- 646. doi:10.1016/S0969-5931(02)00042-2

Neter, J., Wasserman, W., Kutner, M., 1985. Applied Linear Statistical Models. Homewood, Irwin.

North, D., Weingast, B., 1989. Constitutions and Commitment: The Evolution of Institutional Governing Public Choice in 17th Century England. The Journal of Economic History 69, 803-832. doi:10.1017/S0022050700009451 
North, D., 1990. Institutions, Institutional Change and Economic Performance. Cambridge University Press, Cambridge. doi:10.1017/CBO9780511808678

North, D., 1991. Institutions. Journal of Economic Perspectives 5, 97-112. doi:10.1257/jep.5.1.97

Oliver, C., 1997. Sustainable Competitive Advantage: Combining Institutional and Resource Based Views. Strategic Management Journal 18, 697-713. doi:10.1002/(SICI)1097-0266(199710)18:9<697::AIDSMJ909>3.0.CO;2-C

Olson, M., 2000. Power and Prosperity: Outgrowing Communist and Capitalist Dictatorships. Basic Books, New York.

Peng, M., Wang, D., Jiang, Y., 2008. An Institution-Based View of International Business Strategy: A Focus on Emerging Economies. Journal of International Business Studies 39, 920-37. doi:10.1057/palgrave.jibs.8400377

Porter, M., 1985. Competitive Advantage: Creating and Sustaining Superior Performance. The Free Press, New York.

Ramamurti, R. and Singh, J., 2009. Emerging Market Multinationals in Emerging Markets. Cambridge University Press, Cambridge. doi:10.1017/CBO9780511576485

Ramamurti, R., 2009. What have we learned about Emerging-Market MNEs? In: Ramamurti R., Singh J.V., (Eds.), Emerging Multinationals in Emerging Markets, Cambridge University Press: Cambridge, pp. 399-426. doi:10.1017/CBO9780511576485.013

Ramamurti, R., 2012. What is Really Different about Emerging Market Multinationals?. Global Strategy Journal 1, 41-47. doi:10.1002/gsj.1025

Sandholz, W., Taagepera,R., 2005. Corruption, Culture and Communism. International Review of Sociology 15, 109-131. doi:10.1080/03906700500038678

Sauvant, K., 2005. New Sources of FDI: The BRICs Outward FDI from Brazil, Russia, India and China. The Journal of World Investment \& Trade 6 , 639709.

Scott, W., 1995. Institutions and Organizations. Sage Publications, Thousand Oaks.

Scott, W., 2001. Institutions and Organizations. 2nd Ed, Sage Publications, Thousand Oaks. 
Smith, A., 1976. The Wealth of Nations. University of Chicago Press, Chicago.

Tintin, C., 2013. The Determinants of Foreign Direct Investment Inflows in the Central and Eastern European Countries: The Importance of Institutions. Communist and Post-Communist Studies 54, 287-298. doi:10.1016/j.postcomstud.2013.03.006

Train, K., 2003. Discrete Choice Models with Simulation. Cambridge University Press, Cambridge. doi:10.1017/CBO9780511753930

Trevino, L., Daniels, J., Arbelaez, H., 2002. Market Reform and FDI in Latin America: An Empirical Investigation. Transnational Corporations 11, 3048 .

Wei, S., 2000. How Taxing is Corruption on International Investors?. Review of Economics and Statistics 82, 1-11. doi:10.1162/003465300558533

Wheeler, D., and Mody, A. 1992. International Investment Location Decisions: The Case of U.S. Firms. Journal of International Economics 33, 57-76. doi:10.1016/0022-1996(92)90050-T

Yang, X., Jiang, Y., Kang, R., Ke, Y., 2009. A Comparative Analysis of the Internationalization of Chinese and Japanese Firms. Asia Pacific Journal of Management 26, 141-62. doi:10.1007/s10490-007-9065-0

Yaprak, A., Karademir, B., 2010. The Internationalization of Emerging Market Business Groups: An Integrated Literature Review. International Marketing Review 27, 245-262. doi:10.1108/02651331011037548

Yeaple, S., 2003. The Complex Integration Strategies of Multinationals and Cross Country Dependencies in the Structure of Foreign Direct Investment. Journal of International Economics 60, 293-314. doi:10.1016/S00221996(02)00051-X 


\section{Appendix}

Table 1A - Country Subsets: Names and ISO Codes

\begin{tabular}{|c|c|c|}
\hline \multicolumn{3}{|c|}{ Country (ISO code) } \\
\hline EU27 & EU15 & CEECs \\
\hline Austria (AT) & Austria (AT) & Bulgaria (BG) \\
\hline Belgium (BE) & Belgium (BE) & Czech republic (CZ) \\
\hline Bulgaria (BG) & Denmark (DK) & Estonia (EE) \\
\hline Cyprus (CY) & Finland (FI) & Hungary (HU) \\
\hline Czech republic (CZ) & France (FR) & Latvia (LV) \\
\hline Denmark (DK) & Great Britain (GB) & Lithuania (LT) \\
\hline Estonia (EE) & Germany (DE) & Poland (PL) \\
\hline Finland (FI) & Greece (GR) & Romania (RO) \\
\hline France (FR) & Ireland (IE) & Slovakia (SK) \\
\hline Great Britain (GB) & Italy (IT) & Slovenia (SI) \\
\hline Germany (DE) & Luxembourg (LU) & \\
\hline Greece (GR) & Netherlands (NL) & \\
\hline Hungary (HU) & Portugal (PT) & \\
\hline Ireland (IE) & Spain (ES) & \\
\hline Italy (IT) & Sweden (SE) & \\
\hline Latvia (LV) & & \\
\hline Lithuania (LT) & & \\
\hline Luxembourg (LU) & & \\
\hline Malta (MT) & & \\
\hline Netherlands (NL) & & \\
\hline Poland (PL) & & \\
\hline Portugal (PT) & & \\
\hline Romania (RO) & & \\
\hline Slovakia (SK) & & \\
\hline Slovenia (SI) & & \\
\hline Spain (ES) & & \\
\hline Sweden (SE) & & \\
\hline
\end{tabular}

Source: International Organization for Standardization, 2012 


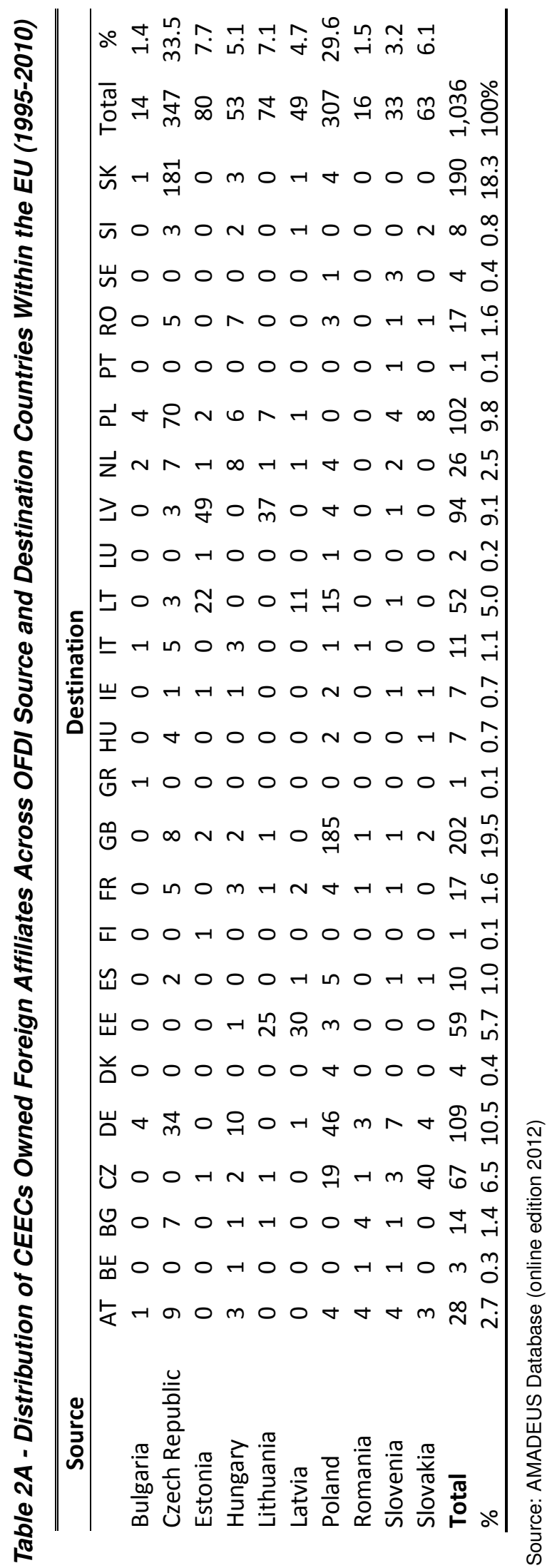




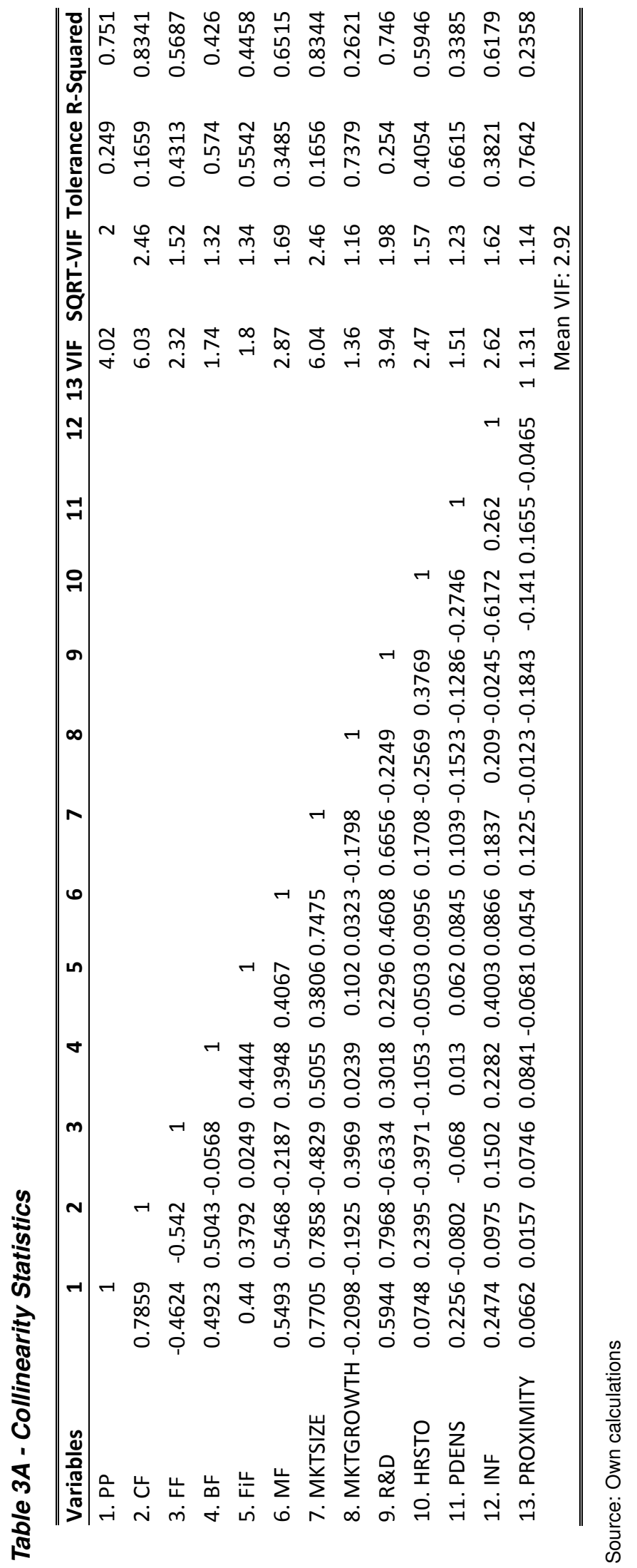

http://www.rei.unipg.it/rei/article/view/139 